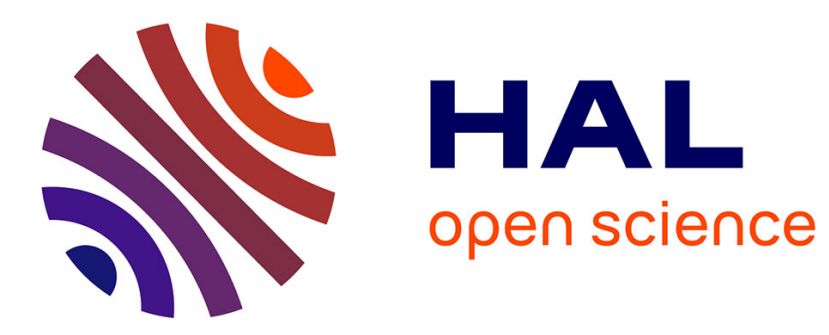

\title{
Specific linguistic profiles in a Creole-speaking area: Children's speech on Reunion Island
}

\author{
Mylène Lebon-Eyquem
}

\section{To cite this version:}

Mylène Lebon-Eyquem. Specific linguistic profiles in a Creole-speaking area: Children's speech on Reunion Island. First Language, 2015, 35 (4-5), pp.327-340. 10.1177/0142723715617875 . hal01501119

\section{HAL Id: hal-01501119 \\ https://hal.univ-reunion.fr/hal-01501119}

Submitted on 11 Oct 2017

HAL is a multi-disciplinary open access archive for the deposit and dissemination of scientific research documents, whether they are published or not. The documents may come from teaching and research institutions in France or abroad, or from public or private research centers.
L'archive ouverte pluridisciplinaire HAL, est destinée au dépôt et à la diffusion de documents scientifiques de niveau recherche, publiés ou non, émanant des établissements d'enseignement et de recherche français ou étrangers, des laboratoires publics ou privés. 


\title{
Specific linguistic profiles in a Creole-speaking area: Children's speech on Reunion Island
}

\author{
Mylène Lebon-Eyquem
}

Université de La Réunion, Reunion Island

\begin{abstract}
Linguists use the concept of diglossia to describe any sociolinguistic situation where a low-prestige dialect coexists with a high-prestige one and these dialects are used in different social spheres. Recent observations on Reunion Island have challenged this view because people mix French and Creole extensively in the same utterance and even in the same word. Prudent accounted for the flexibility of these intermediate linguistic forms through the concept of interlect. Children are exposed at an early age to such intermediate mixed forms and in an earlier study the author suggested five language profiles for young children's use of mixing. The current study surveyed I 10 five-year-old children on Reunion Island to further validate these profiles. The data analysis focuses on one variable, verb forms, which allow the identification of three production types: French, Creole and interlectal forms. Based on these data a language profile for each participant was identified. The children varied in their use of Creole and French, with the largest group of children being Creole 'asymmetric', whereby their speech was dominated by Creole but also included a significant amount of French. The majority of children aged 5 speak little or minimal French.
\end{abstract}

\footnotetext{
Corresponding author:

Mylène Lebon-Eyquem, Département de Lettres, Université de La Réunion, Campus Universitaire du Moufia, 15 Avenue René Cassin, 97715 Saint-Denis, Cedex 9, Reunion Island.

Email: myleneeyquem@yahoo.fr
} 


\section{Introduction}

Situated in the southwest part of the Indian Ocean, $800 \mathrm{~km}$ to the east of Madagascar, Reunion Island forms the Mascarene Archipelago with Mauritius and Rodrigues.

In addition to their significant geological differences, the four neighbouring islands differ in economic, political and sociological terms. While Reunion became a French department in 1946 (and is thus governed by France, follows French legal and educational systems and the official language is French), other island territories chose to become independent (Madagascar in 1960, Mauritius in 1968). The political status of Rodrigues means the island receives support both from France and the European Union. Consequently, Reunion Island projects the image of a prosperous island compared to Madagascar, the Islamic Federal Republic of the Comoros, or even Mauritius (located only $200 \mathrm{~km}$ away). However, Reunion also differs from mainland France. In 2005, the gross domestic product (GDP) of Reunion represented only $0.65 \%$ of French GDP, and the unemployment rate is three times higher than in mainland France $(24.5 \%$ in 2008 as against $7.9 \%$ ).

Aspects of Reunion's particular situation result from the rapid pace of significant social change that has taken place over the past quarter of a century. Reunion differs from mainland France and the other neighbouring islands linguistically. While French is the official language of Reunion, the majority of Reunionese use Creole in daily life. Many people also speak French, and frequent combining of the two languages has yielded a 'mixed' variety - a term speakers themselves use. While codeswitching phenomena are apparent, there is also evidence of other more original and unpredictable communicative strategies. Children are exposed to such linguistic productions early in life and this article explores some of the variation in language use based on social variables. This is especially so for the Reunion Island context: because Creole languages are sometimes seen as less prestigious language variants, they are not usually captured in formal assessment situations such as in standardized tests. However, when Creole-speaking children are tested in Creole, their language scores are significantly better than when tested in the dominant language (Wheldall \& Joseph, 1986; see also Beyer \& Kam, 2012). Hence, it is important to collect information on the variety of patterns of language used in such multilingual communities.

The research presented here is part of a larger study that is attempting to capture the language usage patterns of Reunionese children. In previous work, we conducted initial longitudinal surveys in which we collected data from approximately 20 children aged between 3 and 7 years, from whom we identified five main linguistic profiles (LebonEyquem, 2016). In this article I continue this work by adopting a more quantitative approach. To this end, I focus on the spontaneous speech of 110 children aged 5 years, who were recorded in school and family settings with the aim of specifying the characteristic features of each linguistic profile.

First, salient features of Reunionese morphosyntax are presented. Then, I consider specific characteristics of language acquisition in Reunion and children's patterns of language usage. I then proceed by outlining the methodology, as well as the analytical procedures adopted. Finally, I detail the results of the research. 


\title{
Reunionese productions: Variability, originality and the merging of codes
}

In Reunion, utterances in which French (in regular font formatting) and Creole (in bold) are mixed often occur, as shown in example 1 .

\section{Example 1}

During a meal with local Reunionese friends, Mrs A (27 years old) gives her opinion on the use of social benefits by some Reunionese people:

\begin{abstract}
Mrs A: moin mi pans ke na de moun i fé nimport koi / oui zot i exajèr / zot i fé ninport koi èk larzan i donn azot / par exanp mon voizin / moi je l'aime bien / c'est pas le problème / li travay pa / bin li fé pa rien/li sava pa esay fé in nafèr / mi koné pa moin / kom ramas fèy / nétoy le kour de moun / non / li va pa fé rien / moi je dis oui / on peut essayer de faire quelque chose de ses dix doigts / kosa i kout ali saroy de boi lé dann son kour / mé non / li utilizra tout larzan la donn ali pou asté téléphone / mèt parabol / bin moin lé pa dakor / pars ke larzan i donn ali sé nou qui pay / sé nou ki donn ali èk nout zinpo (I think what some people do is complete nonsense / yes they exaggerate / what they do with the money they are given is nonsense / my neighbour for instance / I like him / that is not the problem / he does not work / he does nothing / he's not going to try to do something / I don't know / like collecting leaves / cleaning people's gardens / No, he won't do anything / I say Ok one can try to do something / What would it cost him to carry the branches from his garden / but no / he will use all the money he gets to buy a telephone / to get cable TV / well I disagree with that / because the money he receives, well we pay for it / we give it to him through the taxes we pay).
\end{abstract}

French may now be used in the private sphere during friendly discussions as illustrated in this example, or during parent-child interactions, which implies that its functional distribution in the Reunionese enunciative space described by the end of the 1960s (by the researchers quoted previously) is no longer strictly adhered to. Furthermore, thanks to its increasing use in the media, Creole is no longer confined to the private sphere.

Since 2000, evidence of 'mixed' productions of forms resulting from 'transfers' between Creole and French (with no hierarchy, no implication) has prompted some researchers (Adelin, 2007; Georger, 2004; Ledegen, 2010) to question the assumption of the existence of an implicational scale. The transcribed excerpt above is an example of how, within the same utterance, the speaker uses basilectal phonological variants [i] in 'li' (il/he) or [s] in 'asté' (acheté/bought), ${ }^{1}$ and basilectal lexical variants of the lexeme 'transporter' (to carry) ('saroyé'). As well, the speaker combines these with a morphological acrolectal variant (line 6) composed of the post-verbal marker 'ra' in 'utilisera' (will use) to indicate the future. In basilectal Creole, we would have expected 'li va utiliz' because in basilectal Creole aspect (here prospective aspect) is expressed by pre-verbal markers (Cellier, 1985).

This concurrence of acrolectal and basilectal variants was observed by Prudent (1981) in Martinique, who recognized a linguistic system comprising two extreme poles corresponding to prototypical Creole and French. He regarded intermediate 'mixed' forms, which he named 'interlect', as common, and showed that the 'interlectal area conformed neither to the nuclear basilect nor to the acrolectal grammar' (Prudent, 1981, p. 26). 


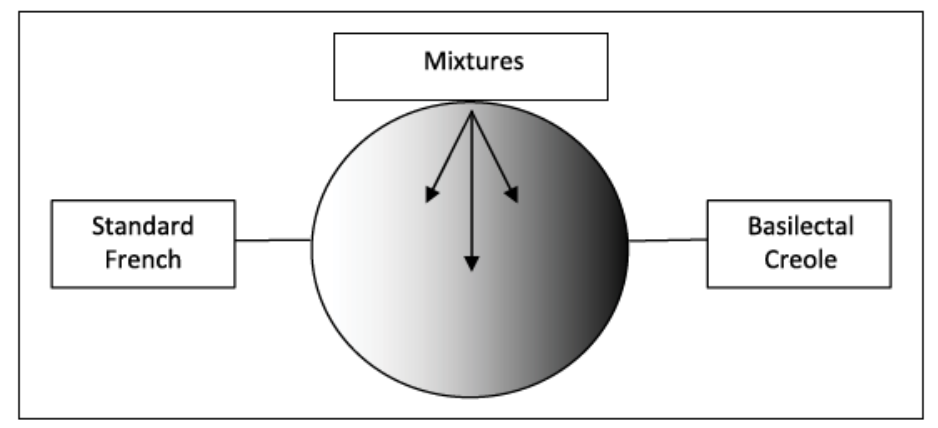

Figure I. The Reunionese macrosystem.

Source: Prudent (198I).

Items that ordinarily occur in French could be included within a Creole syntax utterance and some Creole morphosyntactic elements may be found in French utterances, thus having the appearance of code-switching or borrowings. However, when the languages are 'mixed', the rules of the two concurrent codes are liable to be infringed, which may generate varied and unpredictable forms. A similar phenomenon has been described on Reunion Island (Lebon-Eyquem, 2004, 2007). For Reunionese speakers, the interlect is part of a style, a new textual flow, a new rhythm, owing to new associations which allow speakers to establish a type of privileged communication.

These mixed forms are difficult to codify. In many other situations where two languages are used in language contact situations (e.g. French and English in Canada), we expect the language units to be easily identifiable in utterances. In Creole contexts it is not so easy because of the close genetic relationship between the languages and the fact one language is lexified by the other. Consequently, it is sometimes difficult to assign items to one or other of these languages. According to Bollée (1987), $60 \%$ of Creole lexical items correspond to contemporary French cognates, which entails that one of their semantic values or more may be found in a dictionary like Le Petit Robert, a popular compact French dictionary containing common core vocabulary items. Furthermore, the norms of Creole are varied and reference works far from homogeneous (Adelin, 2007, 2008; Lebon-Eyquem, 2007), making categorization decisions even more difficult. Prima facie, some code-switching processes appear easy to pick out. Thus, we could conclude that in 'ce n'est pas le problème' (that's not the problem) / 'li travay pa' (he doesn't work), the first segment in French is coupled to a second one in Creole (in bold). However, in Creole, we also say 'le problème', and similarly we find 'travaille pas' in French. So, another equally valid analysis would be that the first segment consists of Creole items and the second of French ones. It was very difficult to choose between contradictory analyses. I explain below how we came to determine what is French and/or Creole.

\section{Productions of children are complex and diversified in Reunion}

The lects of the macrosystem (Figure 1) in Reunion are more varied than expected and do not obey a strict functional distribution. 
Table I. The linguistic profiles of Reunionese children.

\begin{tabular}{|c|c|c|c|}
\hline \multirow[t]{2}{*}{ Language profile } & \multirow[t]{2}{*}{$\begin{array}{l}\text { Dominant in either } \\
\text { French or Creole }\end{array}$} & \multicolumn{2}{|c|}{$\begin{array}{l}\text { Equally dominant in both French or Creole (with } \\
\text { no code dominance) }\end{array}$} \\
\hline & & Bilinguals & Mixed-linguals \\
\hline Characteristics & $\begin{array}{l}\text { Only use one language } \\
\text { (Creole or French) in } \\
\text { most cases } \\
\text { Produce numerous } \\
\text { mixtures when they do } \\
\text { not have appropriate } \\
\text { language material } \\
\text { Understand the rules } \\
\text { of usage but cannot } \\
\text { respect them when } \\
\text { they have to use their } \\
\text { less proficient code }\end{array}$ & $\begin{array}{l}\text { Use each code } \\
\text { according to the } \\
\text { communication } \\
\text { situation } \\
\text { Produce few mixtures } \\
\text { Respect the rules of } \\
\text { usage }\end{array}$ & $\begin{array}{l}\text { Use neither French nor } \\
\text { Creole alone } \\
\text { Produce many mixed } \\
\text { utterances whatever } \\
\text { the communication } \\
\text { situation is } \\
\text { Neither know nor } \\
\text { respect the rules of } \\
\text { usage }\end{array}$ \\
\hline
\end{tabular}

Source: Adelin (2008, p. 360).

Even in formal school situations when French is the required language, teachers, whether they are talking to other adults (colleagues or municipal employees) or to pupils, sometimes use 'hybrid' forms of utterances (Lebon-Eyquem, 2010a). Consequently, the Reunionese child in the process of acquiring these languages receives different formal inputs (that even specialists do not always manage to identify) from the same speaker and in the same space. Thus, 'the learner is exposed to many idiolects, none of them being identical to the idiolect that he builds for himself, when all have contributed, in different ways, to the building of that particular idiolect' (Mufwene, 2005, p. 71).

Yet, as Noyau (1998) writes, the child has to distinguish the different utterances received, determine the prototypical features of the two languages, identify and then respect the norms to be used. This explains why the engagement in all those cognitive activities, particularly essential to the acquisition of vocabulary and morphosyntax in a Creole environment (Adelin, 2008; Lebon-Eyquem, 2007, 2010b), does not yield exactly equivalent outcomes for everyone. Hence, Lebon-Eyquem (2012) showed that of 100 children aged between 6 and 7, only 50 managed to differentiate between the relevant codes, while only 70 (of 100) participants aged between 10 and 11 could.

The productions of the children from Reunion vary according to their skills in French; Adelin (2008) distinguishes three main linguistic profiles (Table 1).

However, a 36-month longitudinal study on language use in a school and familial sphere of 20 children (aged 3 at the beginning of the survey) raised questions about this categorization. Although the study appears to validate two of the profiles proposed by Adelin (bilinguals and French dominant speakers, see Table 1), it also showed that two other profiles need to be considered. In particular, the study revealed a problem with identifying a 'Creole dominant' profile because of difficulties in identifying linguistic segments as purely Creole or as mixed forms (including also ambiguous utterances for 


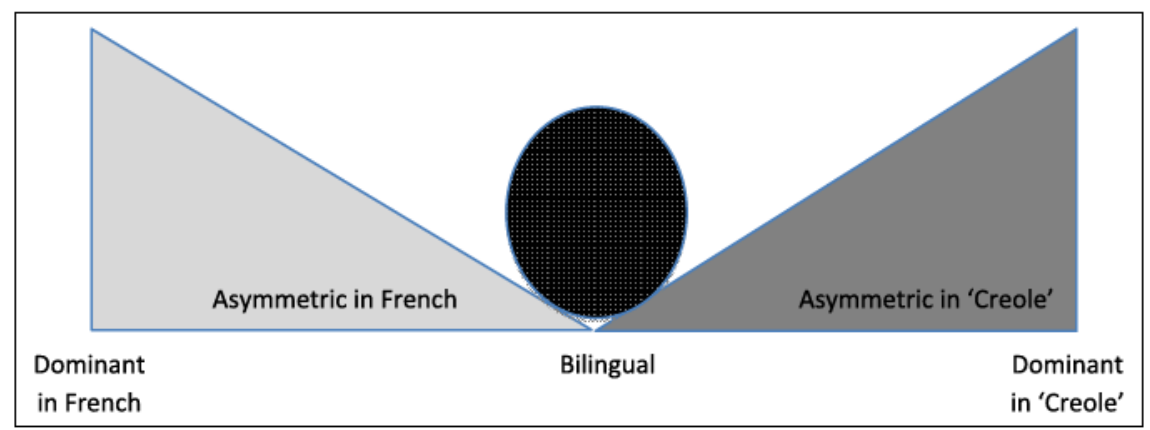

Figure 2. The linguistic profiles of Reunionese children.

coding purposes). Although Creole is used more and more in the media, French remains dominant particularly with new communication technologies, and use of Creole exclusively - that is, Creole entirely on its own - occurs infrequently in Reunion. In order to indicate some of these reservations, inverted commas are now used with the term 'Creole', so the profile has been recast as 'dominant in "Creole" ' (see Figure 2).

Other issues may be associated with the features described in Table 1.

Mixed-linguals appear to lack proficiency and the ability to control the norms of language usage in either French or Creole on account of their production of mixed forms. Their language use may then be judged negatively because it is perceived as the result of a 'language deficit', when in fact it testifies to rich interactional processes. Indeed, some interlectal utterances show an elaborate linguistic competence (Georger, 2004; LebonEyquem, 2007). So, the main point that the way the mixed-linguals are described in Table 1 encourages a deficit interpretation.

The production of mixed forms should not be considered as a criterion to differentiate between profiles, as in a situation of language contact mixtures necessarily occur: 'research on bilingual speech shows that the linguistic systems composing the plurilingual repertoire contain the signs of contact between the different languages' (Moore, 2006, p. 94).

For such reasons, the mixed-lingual profile from Table 1 was considered highly problematic for the current study. In its place, two separate groupings have emerged which include speakers with asymmetric use of French or Creole, who produce both of these codes in very different proportions. The five profiles are represented in Figure 2.

In the middle, the bilingual speakers have a particularly diverse language repertoire including different lects of the macrosystem ('Creoles', Frenches and mixtures) that they manage to vary and activate according to the communication situation.

On either side of the bilingual speakers, we find 'asymmetric' groups, whose linguistic systems have a stratified-type of internal organization. On the one side is 'asymmetric' in French. Here the language use of such speakers could be placed on a continuum, at one end of which are the productions of French dominant individuals (having a repertoire limited almost to French only) while the other end is represented by the productions of bilinguals. Between these two extremes we find intermediate forms comprising French and varying proportions of 'Creole', which allocate speakers to different points on the 
continuum. Thus, the closer speakers get to the bilingual end of the continuum, the more their French productions are likely to include some 'Creole'.

Within the 'asymmetric' in 'Creole' side of the diagram, the speakers' language use could be placed on a second continuum where one end consists of productions of Creole dominant individuals (having a repertoire with a large proportion of 'Creole' forms) with the other end represented by productions of bilinguals. Between these two extremes, we find intermediate forms comprising Creole and a proportion of French which vary according to the position of the speaker on this continuum compared to either extremity. Thus, the asymmetric speaker in 'Creole' closer to the bilinguals will gather more utterances in French than the one who is further away.

\section{Method}

The above discussion informed the research methodology. The research focused on expanding understanding of the posited language profiles by determining the proportion of children on Reunion Island that belong to each. The study also investigated the characteristics of participants belonging to each group, including gender, socio-professional status of parents and parental attitudes towards languages.

\section{Participants}

We recruited children aged 5 years to participate, as they were more likely to produce enough data to reliably classify them into the five categories.

Many variables were taken into account in the choice of prospective participants. In particular, we considered the social status of children's parents to be important as, for instance, Crémieux (2000) notes it has a strong influence on the linguistic choice of families. The middle class of the island, which corresponds more or less to the lower bourgeoisie (often including civil servants), tends to be hostile towards Creole and wishes to speak French as the only authorized code in the family circle. It has also been found that mothers from modest origins (whose income is below the minimum wage) adopt the same attitude to conform to the models of mothers from the middle class because they aspire to the professional and social success of their children. Parental opinions on languages and the family's language behaviours and decisions influence their children's choice of language or variety of language.

We also gave careful consideration to the gender balance of participants. In total, we recruited 110 children aged from 5;0 to 5;6 (mean age, 5.4). The children were all born on Reunion Island and had always lived there. Gender was evenly distributed (55 females).

Participating children were drawn from the different areas of the island. The family incomes of participating children were distributed as follows: $<1000$ euros $/$ month $(15 \%)$, $1000-2000$ euros/month (32\%), 2000-4000 euros/month (35\%), > 4000 euros (18\%).

\section{Procedure}

For the children in the school setting, we recorded interactions between peers inside and outside the classroom. We also focused on two other sources of likely impact on 
children's linguistic practices: the teacher and his/her aide. We filmed their exchanges with each child in formal situations of learning and informal settings (when children were working independently, when they arrived at school in the morning, when they were in the canteen, etc.). As it is in the family circle that children are initially socialized (Labov, 1976), we recorded each participating child at home twice, at six-month intervals, in order to capture the influence of different family members on the linguistic usage.

We also conducted some semi-structured interviews with the parents primarily with a view to collecting their opinions on the languages/lects in contact situations and to better understand their attitudes towards particular sociolinguistic phenomena. It is likely that parents' opinions have an impact on their language use and linguistic choices for their children. We also asked parents to tell us about their linguistic choices in their household. We wanted to know what parents claimed they corrected in their children's language use, if they expressly and openly asked them to 'speak French' or 'speak Creole', or if they just recommended them to speak French or Creole.

For each child and for each type of observation recorded (depending on the place and the interlocutors), a sample of 50 utterances for each child was chosen for analysis (following Rondal, 1997; Rondal \& Seron, 1999). Each sample is made up of several discursive sequences which include verb forms.

\section{Analysis}

We observed the linguistic forms used by each child by focusing on the morphology of the verb as 'verbs and variations of forms are a domain where the differences between languages are particularly specific and substantial' (Bassano, Maillochon, Klampfer, \& Dressler, 2001, p. 85), and in that inflectional morphemes of French verbs vary according to subject and person, but do not in Creole. In addition, some Creole speakers use pre-verbal markers to indicate tense and aspect, whereas these categories are expressed through inflectional morphemes in French: for example, 'Nathalie té i boir' $(\mathrm{CR}=$ té i); 'Nathalie buvait' (FR = -ait) (Nathalie used to drink). Furthermore, the construction of the infinitive is different in the two languages: the infinitival form is invariant in French but two context-dependent forms may occur in Creole. For instance, the French infinitive 'apporter' (to bring) could take the form of 'aport' or 'aporté', as the form of an infinitive in Creole depends on the absence or presence of a complement directly after the verb: 'nou va aporté' (nous allons l'apporter; we will bring it) et 'ou va aport in marmit' (nous allons apporter une marmite; we will bring a pot).

Our procedure followed two steps for each utterance: first we identified the verb phrase and, within the limitations established, we attempted to identify two main types of linguistic forms. The results are presented in Table 2.

Note that intra-systemic attempts (hesitant approximations of the child in a particular code) are counted in the corresponding code. For instance, the non-standard form 'il a coudé' (for 'il a cousu'; he sewed) was considered as French and not as Creole or mixed.

Homophonous French and Creole forms were difficult to distinguish. To determine whether a form was French or Creole, we relied on contextual linguistic and extra-linguistic clues, which clarified some ambiguities. If any doubts remained, we did not count those 
Table 2. Mixed utterance types.

Socially established 'mixed' forms (socially accepted and used in the daily utterances)

Intra-utterance code-switching (segments in

Creole contiguous to segments in French)

or inter-utterances (utterances in Creole

contiguous to French utterances)

Utterances with alternating Creole units and

French units but also containing units hard

to codify (underlined in the example)

Ungrammatical and 'mixed' language forms

Attempts and hypotheses that do not follow the rules of either French or Creole

Situations where the speaker aims at a target language 'ma la parti la kaz akoz / euh il y avait pas d'école' (I went home because / there was no school)

'li té gagn pa / li fé pa dé jèst kom sa / lui il fait pas ça / lui' (he couldn't do it / he does not do such things / he does not do that)

'il prenait la feuille / euh / il / il té i regarde l'herbe' (he took a leaf / mmh / he was looking at the grass)

Expected form in Creole: li té $\mathbf{i}$ gard zèrb

Expected form in French: il regardait l'herbe (he was looking at the grass)

utterances. After the utterances of each child were analysed, the most frequent verb forms were catalogued, and their linguistic profile assigned.

\section{Results}

The number of children assigned to each profile is shown in Table 3. All of our participating children fitted one of the five linguistic profiles posited from previous research (Lebon-Eyquem, 2016). Apart from the group dominant in French, all the children produced mixed utterances that are representative of the heterogeneous character of Reunionese speech.

Children asymmetric in 'Creole' were the dominant group, almost double the next largest grouping, who are dominant in 'Creole'. They are more numerous (41\%) than the children asymmetric in French (15\% of the total). Overall, only $33 \%$ of children used French predominantly (dominant plus asymmetric). Not surprisingly only $3 \%$ of children were categorized as bilingual, such that they could mobilize both codes and adapt them 'correctly' to the context of communication, given that Moore (2006) argues that it is difficult to possess the same skills in both languages in multilingual situations, as shown in Table 4.

Table 4 shows the distribution of children by gender per linguistic profile. Girls dominated the French, asymmetric in French and bilingual groups (respectively $+20 \%$ and $+28 \%$ and $+33.4 \%$ more than boys), suggesting that more girls than boys speak French. Slightly more boys are asymmetric in 'Creole' ( $+6.8 \%$ more than girls) but many are dominant in 'Creole' $(+28 \%$ more than girls). So, in looking for explanations for this trend, we turn our attention to the impact of families, whose language choices may differ depending on whether the child is a male or female.

The parents of children dominant in French, or bilingual, earn the highest incomes, closely followed by the parents of children asymmetric in French, with half the parents 
Table 3. Numbers of children in each profile and their relative proportion (as a percentage).

\begin{tabular}{|c|c|c|c|c|c|c|}
\hline & $\begin{array}{l}\text { Dominant in } \\
\text { French }\end{array}$ & $\begin{array}{l}\text { Asymmetric } \\
\text { in French }\end{array}$ & Bilingual & $\begin{array}{l}\text { Asymmetric } \\
\text { in 'Creole' }\end{array}$ & $\begin{array}{l}\text { Dominant } \\
\text { in 'Creole' }\end{array}$ & Total \\
\hline Number of children & 20 & 17 & 3 & 45 & 25 & 110 \\
\hline Relative proportion & $18 \%$ & $15 \%$ & $3 \%$ & $41 \%$ & $23 \%$ & $100 \%$ \\
\hline
\end{tabular}

Table 4. Distribution in number and in percentage of the participants by gender in each linguistic profile.

\begin{tabular}{lcccccc}
\hline & $\begin{array}{l}\text { Dominant } \\
\text { in French }\end{array}$ & $\begin{array}{l}\text { Asymmetric } \\
\text { in French }\end{array}$ & Bilingual & $\begin{array}{l}\text { Asymmetric } \\
\text { in 'Creole' }\end{array}$ & $\begin{array}{l}\text { Dominant } \\
\text { in 'Creole' }\end{array}$ & Total \\
\hline Number of girls & $12(21.8 \%)$ & $11(20.0 \%)$ & $2(3.6 \%)$ & $21(38.2 \%)$ & $9(16.4 \%)$ & $55(100 \%)$ \\
Number of boys & $8(14.5 \%)$ & $6(11.0 \%)$ & $1(1.9 \%)$ & $24(43.6 \%)$ & $16(29.0 \%)$ & $55(100 \%)$ \\
\hline
\end{tabular}

of children dominant in French or asymmetric in French having an income exceeding 4000 euros a month, the remainder earning between 2000 and 4000 euros a month. The bilingual children also came from high income families ( 2 families earning $>4000$ euros per month, and 1 earning 2000-4000 euros per month). No parents of French dominant or bilingual children earned less than 2000 euros per month. Accordingly, it seems that children using predominantly French come from higher income families.

The majority of the parents of children dominant in 'Creole' had incomes lower than 1000 euros a month while in the asymmetric 'Creole' group, half earned 1000-2000 euros a month while the other half earned 2000-4000 euros a month. Therefore, parents earning 2000-4000 euros a month are producing Creole-speaking children as well as children who are dominant, asymmetric or bilingual in French.

\section{Distribution of children in each linguistic profile according to linguistic choices}

During the semi-structured interviews conducted at home with parents, and the recordings of children in the home environment, we observed that some parents encouraged their children, sometimes strongly, to use French and/or Creole while others did not. A minority of the parents of children asymmetric in 'Creole' $(20 \%)$ encouraged their child to use both languages but no family indicated that they encouraged their child to use 'Creole' only.

The parental instructions/encouragement to use French appeared effective for the children dominant, asymmetric and bilingual in French, but not for children who are asymmetric in 'Creole'. Children who are dominant in 'Creole' - whether boys and girls - tend not to receive or be given recommendations about which language to use, and continue to use the language they started to talk with, 'Creole'.

Most parents involved in the study have positive views about Creole, regardless of their children's linguistic profile. These findings corroborate those of Bavoux (2002) and 
those of Rapanoël (2007), who noticed a certain 'easing of tension' towards Creole and suggest that Creole is less stigmatized than it was 40 years ago. At the end of the $1970 \mathrm{~s}$, Gueunier, Genouvrier, and Khomsi (1978) reported very demeaning judgements about Creole from a large majority of Reunionese: Creole was then considered as a 'language' that was young, with a poor vocabulary, no syntax, and as exclusively oral, thereby making it impossible to normalize and teach. However, in the past 10 years or so, the Reunionese have come to recognize the legitimacy of 'Creole' and interlectal forms appear these days in the public arena where they were once considered less than acceptable. Written Creole can be seen in posters, leaflets and television spots. What is more, surveys on the pragmatic efficiency of commercial brands and other advertisements have shown that the Reunionese appreciate the use of Creole or other hybrid forms because they find them 'appealing, funny, pleasant, friendly and folkloric', and those surveyed agreed that they feel happy and proud to see the Reunionese identity respected in this way (Lebon-Eyquem, 2008, p. 197). Hence, the conflict between French and Creole has diminished over the years. Thus, some of our participants' parents reported that they value both languages ( $60 \%$ of positive views on Creole and $100 \%$ for French among the parents of asymmetric children in 'Creole', and 50\% and $100 \%$ among the parents of bilingual children, for instance).

Ninety percent of parents of children dominant in 'Creole' and $60 \%$ of parents of children asymmetric in 'Creole' indicated they were in favour of Creole, although all of the latter group reported that they implore their children to use French only because they think that French will allow their children to find a job and earn a high salary. Meanwhile, $70 \%$ of the parents of children dominant in Creole do not recommend using one language or another because they lend no importance to this matter.

Although a significant proportion of the parents of children dominant, asymmetric and bilingual in French view Creole favourably, they also want their children to only speak French. For these parents, Creole is not a serious alternative because it would imply competition with French, which has occupied a prestigious place for years and is still highly valued by all the parents in our study. Therefore the Reunionese epilinguistic framework continues to assign the status of low prestige to Creole and high prestige to French.

\section{Conclusion}

Within Reunionese society, where Creole, French and language-mixing create a complex multilingual situation, different language profiles of young children have been identified (Lebon-Eyquem, in press). In the current study we aimed to identify the degree to which a representative sample of 5-year-old Reunionese children could belong to one of these profiles.

In each of the five groups, speech is organized according to flexible, dynamic and different combinations. The group asymmetric in 'Creole' proved to be a large majority and, if the group dominant in 'Creole' is included, it can be concluded that the majority of children aged 5 speak little or minimal French. Yet, this language remains the prestige variety among parents. Creole seems to be less stigmatized nowadays than it was, even though it remains largely confined to informal situations. Thus, the role of parents' 
instructions regarding which language to use and their conception of languages are substantial, but they do not account for all the linguistics profiles drawn in this study. This research also sheds new light on the relationships between social-professional groups and language use. In privileged social groups, children's utterances are predominantly or exclusively French, but those of disadvantaged or modest social background groups utilize some French as well as Creole and mixed productions.

This research indicates that the language use of 5-year old children in this linguistic situation can vary significantly. Nevertheless, it is clear that some languages carry less weight than others and do not have the same power or the same linguistic and symbolic capital. Thus, the use of some lects may not provide the same advantages as others, especially in a diglossic context. For all these reasons, in Reunion, belonging to the group dominant in French is considered by parents to bring greater benefits at a social and institutional level than an association with 'Creole'.

However, plurilingual competence is dynamic:

Depending on the path of the social actor, the configuration of this competence evolves, expands with new components, supplements or transforms others, or even lets some perish. This is the logical outcome of professional, geographical and familial mobility as well as the evolution of personal interests. (Coste, Moore, \& Zarate, 1997, p. 15)

Their life experiences mean the children in this study may change their linguistic profile. It will be interesting to consider the reasons for their trajectory in further research.

\section{Funding}

The author(s) received no financial support for the research, authorship, and/or publication of this article.

\section{Note}

1. The corresponding acrolectal variants are [u] ('lu' for 'il'/he) or [ $\left.\int\right]$ (pronounced as in 'acheté'/bought).

\section{References}

Adelin, E. (2007). La convergence avec le français. Quel créole de référence à la Réunion? [The convergence with French. What Creole of reference to Reunion]. In Maïga, A. (coord.), Le français dans les aires créolophones. Vers une didactique adaptée (pp. 171-183). Paris, France: L'Harmattan.

Adelin, E. (2008). Créole et français de petits écoliers réunionnais. Prolégomènes à l'évaluation de langues proches (Thèse de doctorat) [Creole and French of small pupils from Réunion. Prolegomena in the evaluation of close languages]. Université de la Réunion.

Bassano, D., Maillochon, I., Klampfer, S., \& Dressler, W. U. (2001). L'acquisition de la morphologie verbale à travers les langues: Les fondements théoriques [The acquisition of the verbal morphology through the languages: The theoretical foundations]. Enfance, 53(1), 81-99. 
Bavoux, C. (2002). Représentations et attitudes dans les aires créolophones [Representations and attitudes in the Creole-speaking areas]. In C. Bavoux \& D. de Robillard (Eds.), Linguistique et créolistique. Univers créoles 2 (pp. 57-76). Paris, France: Anthropos.

Beyer, T., \& Kam, C. L. H. (2012). First and second graders' interpretation of Standard American English morphology across varieties of English. First Language, 32, 365-384.

Bollée, A. (1987). Créoles français et français nord américains. In H.-J. Niedereche \& L. Wolf (Eds.), Français standard du Canada, français de France, Actes du Colloque de Trèves [Standard French of Canada, French of France, Acts of the Colloquium of Trier] (pp. 319-333). Tübingen, Germany: Neimeyer.

Cellier, P. (1985). Description syntaxique du créole réunionnais: Essai de standardisation (Thèse de doctorat d'Etat) [Syntactic description of the Creole from Réunion: Try of standardization (Doctoral thesis)]. Université de la Réunion / Université de Provence.

Coste, D., Moore, D., \& Zarate, G. (1997). Compétence plurilingue et pluriculturelle [Multilingual and multicultural competence]. Strasbourg, France: Conseil de l'Europe.

Crémieux, S. (2000). Aspects des politiques linguistiques familiales: comment le créole et le français sont-ils perçus et gérés par les parents réunionnais? (Mémoire de Maîtrise de Lettres Modernes) [Aspects of the family linguistic politics(policies): How the Creole and French are they perceived) and done managed by the parentsfrom Réunion? (Master's essay of Letters Modern)]. Université de La Réunion.

Georger, F. (2004). Didactiser le contact créole/français. L'exemple d'une classe maternelle bilingue à La Réunion (Mémoire de Maîtrise de Lettres Modernes) [Didactiser the Creole/ French contact. The example of a bilingual maternal class in Reunion (Master's essay of Contemporary literature)]. Université de La Réunion.

Gueunier, N., Genouvrier, E., \& Khomsi, A. (1978). Les français devant la norme [French in front of the standard]. Paris, France: Champion.

Labov, W. (1976). Sociolinguistique [Sociolinguistic]. Paris, France: Minuit.

Lebon-Eyquem, M. (2004). Paroles réunionnaises entre créole et français: dynamique conversationnelle et productions interlectales (Mémoire de DEA 'Langage et Parole') [Words from Réunion between Creole and French: Interactive dynamics and productions interlectales (Memory of post-graduate diploma 'Language and Word')]. Université de La Réunion.

Lebon-Eyquem, M. (2007). Une approche du développement langagier de l'enfant réunionnais dans la dynamique créole-français (Thèse de doctorat) [An approach of the linguistic development of the child from Réunion in the Creole-French dynamics (Doctoral thesis)]. Université de La Réunion.

Lebon-Eyquem, M. (2008). Paroles de quatre pré-adolescents citadins à l'île de La Réunion [Words of four city preteenagers in the Reunion Island]. In T. Bulot \& V. Feussy (Eds.), Normes, Urbanités et émergences plurilingues (parlers de jeunes francophones) (pp. 169199). Paris, France: L'Harmattan.

Lebon-Eyquem, M. (2010a). La dodo lé la. Stylistique du 'mélange' à La Réunion: À la recherche de l'efficacité pragmatique endogène ["La Dodo lé la". Stylistics of the 'mixture' in Reunion(Meeting): In search of the endogenous pragmatic efficiency]. In C. Bavoux, L. F. Prudent \& S. Wharton (Eds.), Normes endogènes et plurilinguisme (pp. 153-175). Lyon, France: ENS.

Lebon-Eyquem, M. (2010b). Analyse d'interventions pédagogiques en situation de contacts de langues: Comment les enseignants traitent-ils les énoncés 'melanges' à La Réunion? [Analysis of educational interventions in situation of contacts of languages: How do the teachers handle the statements 'mixtures' in Reunion]. In V. Feussi, M. Eyquem-Lebon, A. MoussirouMouyama \& P. Blanchet (Eds.), Hétérogénéité sociolinguistique et didactique du français. 
Pratiques linguistiques des jeunes en terrains plurilingues (pp. 61-89). Paris, France: CLD éditions.

Lebon-Eyquem, M. (2012). Evolution et impact de l'école et de l'environnement social sur les usages de 4 enfants de 3 ans en milieu créole [Evolution and impact of the school and the social environment on the uses of 43 -year-old children in Creole environment]. In Actes du colloque CMLF 2010. 2ème Congrès Mondial de Linguistique Française. Retrieved from http://dx.doi.org/10.1051/cmlf/2010224

Lebon-Eyquem, M. (2016). Profils langagiers d'enfants en milieu créole. Paris, France: L'Harmattan.

Ledegen, G. (2010). Réalités et paradoxes du contact créole-français à La Réunion: 'tééé atta je te raconte un zaffaire' [Realities and paradoxes of the Creole-French contact in Reunion: 'tééé atta je te raconte un zaffaire']. In E. Wolff \& M. Watin (Eds.), La Réunion, une société en mutation. Univers créoles 7 (pp. 101-121). Paris, France: Anthropos.

Moore, D. (2006). Plurilinguismes et école [Multilingualisms and school]. Paris, France: Didier.

Mufwene, S. (2005). Créoles, écologie sociale, évolution linguistique. Paris, France: L'Harmattan.

Noyau, C. (1998). Temporalité et récit dans l'acquisition du langage en situation bilingue [Temporality and narrative in the language acquisition in bilingual situation]. Linx, 38, 7-18. Retrieved from http://linx.revues.org/847

Prudent, L. F. (1981). Diglossie et interlecte [Diglossia and interlect]. Langages, 61, 13-38.

Rapanoël, S. (2007). Les langues à l'école primaire de la Réunion: des représentations diglossiques aux pratiques interlectales (Thèse de doctorat) [The languages to the primary school of Reunion: Representations diglossiques in the interlectales practices (Doctoral thesis)]. Université Grenoble 3 - Université de la Réunion.

Rondal, J.-A. (1997). L'évaluation du langage [The evaluation of the language]. Bruxelles, Belgium: Mardaga.

Rondal, J.-A., \& Seron, X. (1999). Troubles du langage. Bases théoriques, diagnostic et rééducation [Speech difficulties. Theoretical bases, diagnosis and reeducation]. Liège, Belgium: Mardaga.

Wheldall, K., \& Joseph, R. (1986). Young black children's sentence comprehension skills: A comparison of performance in standard English and Jamaican Creole. First Language, 6, $149-154$. 